\section{Dead Prunus Flower-bud Primordia Retain Deep-supercooling Properties}

\author{
Sorkel A. Kadir ${ }^{1}$ and Ed L. Proebsting ${ }^{2}$ \\ Irrigated Agriculture Research and Extension Center, Washington State \\ University, Presser, WA 99350
}

Additional index words. differential thermal analysis, flower buds, Prunus armeniaca,

Prunus avium, Prunus davidiana, Prunus dulcis, Prunus persica

Abstract. Differential thermal analysis (DTA) was used to measure deep supercooling in flower buds of Prunus dulcis Mill., $P$. armeniaca L., $P$. davidiana (Carr.) Franch, $P$. persica (L.) Batsch, three sweet cherry (P. avium L.) selections, and 'Bing' cherries ( $P$. avium L.) during Winter 1990-91 and 1991-92. Low temperatures in Dec. 1990 killed many flower buds. After the freeze, dead flower primordia continued to produce low-temperature exotherms (LTEs) at temperatures near those of living primordia for $>2$ weeks. In Feb. 1992, cherry buds that had been killed by cooling to $-33 \mathrm{C}$ again produced LTEs when refrozen the next day. As buds swelled, the median LTE $\left(\mathrm{LTE}_{\mathrm{5} 0}\right)$ of dead buds increased relative to that of living buds, and the number of dead buds that produced LTEs decreased. LTE artifacts from dead flower priimordia must be recognized when DTA is used to estimate $\mathrm{LTE}_{50}$ of field-collected samples.

Flower-bud primordia of Prunus species avoid freezing by supercooling water in the bud tissue (Burke and Stushnoff, 1979; Quamme, 1974). Differential thermal analysis (DTA) is a reliable and consistent method to determine the critical temperature for flower buds of cultivated Prunus species. The typical DTA profile of Prunus species consists of two exotherms: high-temperature exotherms and low-temperature exotherms (LTEs). LTEs have been associated with primordia death (Burke and Stushnoff, 1979; Graham and Mullin, 1976; Quamme, 1974). When dormant flower buds are killed, subsequent $\mathrm{LTE}_{50}$ estimates should be based on surviving-bud hardiness. When flower buds are killed, their tissues turn brown within $24 \mathrm{~h}$ of thawing. By artificially freezing and visually detecting dead buds, it is easy to base $\mathrm{LTE}_{50}$ estimates on surviving-bud behavior. It has been reported that dead azalea (Rhododendron kosterianum Schneid.) primordia supercooled (George et rd., 1974), while injured blueberry (Vaccinium corymbosum L.) buds produced no LTEs several days before DTA (Biermann et al., 1979). After the advective freeze that swept through south-central Washington during the last 2 weeks of Dec. 1990, we observed that there were more buds producing LTEs than there were living buds in the sample. $\mathrm{LTE}_{50}$ mea-

Received for publication 2 Nov. 1992. Accepted for publication 11 Mar. 1993. H/LA paper 92-18, project 0215, Washington State College of Agriculture Research Center. This research was supported in part by a grant from the Washington Tree Fruit Research Commission. The cost of publishing this paper was defrayed in part by the payment of page charges. Under postal regulations, this paper therefore must be hereby marked advertisement solely to indicate this fact.

'Postdoctoral. To whom reprint requests should be addressed at Mt. Vernon Research and Extension Unit, 1468 Memorial Highway, Mt. Vernon, WA 98273-9788.

${ }^{2}$ Horticulturist. surements after the freeze were based on the distribution of LTEs from living and dead flower primordia. The objective of this study was to use DTA to measure the extent of supercooling of living and dead flower buds of several Prunus species.

Flower buds of the following Prunus species were collected at the Washington State Univ. Irrigated Agriculture Research and Extension Center, Presser, Wash.: P. davidiana (ornamental), P. dulcis (almond), P. persica (peach), P. armeniaca (apricot), and 'Bing' cherry (P. avium) (Rehder, 195 1). The samples were collected before, during, and after the Dec. 1990 freeze. Samples were placed in plastic bags and stored at $3 \mathrm{C}$ for 2 to 3 days before being prepared in a walk-in refrigerator for DTA. In addition, during February of the mild Winter 199 1-92, samples were collected from 'Bing' cherries and the trees of 7144-3, 7147-13, and 7309-4 sweet cherry selections planted in 1983 at the research orchard.

Ten to 15 flower buds were detached from their twigs with 1 to $2 \mathrm{~mm}$ of bark tissue and placed on both sides of thermoelectric module plates (Andrews et al., 1983). Buds were held in place with aluminum foil. Plates were frozen as reported by Kader and Proebsting (1992). Prunus flower buds were removed from the freezer the next day and placed in $100 \%$ relative humidity at room temperature before being tested for tissue browning.

Duplicate bud samples were collected from the field and observed under a microscope to estimate the extent of flower-bud injury. In 1991-92, there was no damage to cherry flower buds in the field. In Feb. 1992, DTA of living (from the field) and dead (from the samples that were exposed to $-33 \mathrm{C}$ in the freezer) primordia were compared. Dead samples were removed from the freezer and placed on a new (dry) plate, and DTA was repeated. DTAs were run on both samples as before.

Data are expressed as $\mathrm{LTE}_{50}$, the temperature at which $10 \%\left(\mathrm{LTE}_{10}\right)$ and $90 \%\left(\mathrm{LTE}_{90}\right)$ of flower primordia were injured, and the percentage of primordia that produced LTEs.

During the Dec. 1990 freeze, the temperature dropped to $-21.7 \mathrm{C}$ and damaged $P$. dulcis, $P$. davidiana, $P$. avium, $P$. persica, and $P$. armeniaca flower buds. Flower buds of some species were injured before 20 Dec., in the early days of the cold wave. During late December, when $25 \%$ to $96 \%$ of flower buds was injured, DTA recorded almost the same percentage of LTEs at temperatures similar to those of noninjured flower buds measured before the freeze. Whether buds were living or dead, they supercooled. Ninety-six percent of P. dulcis flower buds was injured on $26 \mathrm{Dec}$., yet DTA recorded LTEs similar to those of noninjured flower buds (Table 1). Prunus persica and $P$, armeniaca flower buds supercooled to lower temperatures on 20 Dec. and 2 Jan., respectively, than noninjured buds in early December. Injured buds also produced only slightly fewer LTEs than noninjured buds. On 2 Jan., $P$. avium flower buds (39\% injured) also produced a similar number of LTEs at similar temperatures as noninjured buds.

Living and dead flower buds of the three cherry selections and 'Bing' cherries supercooled during Feb. 1992 (Table 2). Water that remained in dead flower primordia froze at higher temperatures than in living flower buds. As buds developed in late February, $\mathrm{LTE}_{50}$ increased for living and dead primordia. On 26 Feb., when living buds were swelling, dead

Table 1. Median low-temperature exotherm ( $\left.\mathrm{LTE}_{50}\right)$, temperature that kills $10 \%\left(\mathrm{LTE}_{10}\right)$ and $90 \%\left(\mathrm{LTE}_{90}\right)$ of Prunus flower buds, percentage of buds supercooled [LTE/primordium (LTE/P)], and percentage of buds injured before and after the advective freeze that began late Dec. 1990.

\begin{tabular}{|c|c|c|c|c|c|c|}
\hline \multirow{2}{*}{$\begin{array}{l}\text { Measurement } \\
\text { date }\end{array}$} & \multirow[b]{2}{*}{ Species } & \multirow{2}{*}{$\begin{array}{c}\text { Injured } \\
\text { buds (\%) }\end{array}$} & \multicolumn{3}{|c|}{ Mean LTE \pm sD $\left({ }^{\circ} \mathrm{C}\right)$} & \multirow{2}{*}{$\begin{array}{c}\text { LTE/P } \\
(\%)\end{array}$} \\
\hline & & & $\mathrm{LTE}_{10}$ & $\mathrm{LTE}_{50}$ & $\mathrm{LTE}_{90}$ & \\
\hline 13 Nov. & $P$. dulcis & 0 & $-12.3 \pm 0.2$ & $-18.3 \pm 1.7$ & $-20.3 \pm 0.2$ & $66 \pm 2.8$ \\
\hline 26 Dec. & P. dulcis & $96 \pm 4.9$ & $-12.6 \pm 0.3$ & $-17.4 \pm 0.4$ & $-20.8 \pm 0.2$ & \pm 4.2 \\
\hline 11 Dec. & P. armeniaca & 0 & $-21.0 \pm 0.5$ & $-22.2 \pm 0.2$ & $-22.8 \pm 0.1$ & $83 \pm 2.8$ \\
\hline 2 Jan. & P. armeniaca & $69 \pm 1.1$ & $-22.0 \pm 0.7$ & $-23.2 \pm 0.3$ & $-24.5 \pm 0.7$ & $94 \pm 7.1$ \\
\hline 15 Jan. & P. armeniaca & $63 \pm 2.1$ & $-18.5 \pm 0.3$ & $-21.6 \pm 2.2$ & $-23.3 \pm 1.7$ & $78 \pm 4.2$ \\
\hline 20 Dec. & P. avium & 0 & $-21.8 \pm 0.3$ & $-23.5 \pm 0.4$ & $-24.7 \pm 0.2$ & $86 \pm 2$ \\
\hline 2 Jan. & P. avium & $39 \pm 2.1$ & $-20.4 \pm 0.1$ & $-21.9 \pm 0.2$ & $-22.6 \pm 0.4$ & $73 \pm 1.4$ \\
\hline 30 Nov. & P. davidiana & 0 & $-11.7 \pm 0.6$ & $-18.8 \pm 0.4$ & $-22.5 \pm 0.7$ & $89 \pm 1.4$ \\
\hline 22 Dec. & P. davidiana & $37 \pm 7.8$ & $-11.0 \pm 0.1$ & $-15.4 \pm 0.6$ & $-19.0 \pm 0.0$ & $96 \pm 4.9$ \\
\hline 26 Dec. & P. davidiana & $35 \pm 3.5$ & $-12.4 \pm 0.4$ & $-16.4 \pm 0.1$ & $-23.5 \pm 0.7$ & $7 \pm 2.8$ \\
\hline 12 Jan. & P. davidiana & $47 \pm 4.6$ & $-15.4 \pm 0.3$ & $-21.6 \pm 2.1$ & $-24.0 \pm 1.4$ & $8 \pm 2.8$ \\
\hline $5 \mathrm{Dec}$. & $P$. persica & . & $-17.5 \pm 0.7$ & $-20.0 \pm 0.2$ & $-20.3 \pm 0.3$ & $76 \pm 4.2$ \\
\hline 20 Dec. & P.persica & $25 \pm 5.7$ & $-19.5 \pm 0.7$ & $-21.6 \pm 0.6$ & $-22.0 \pm 0.4$ & $67 \pm 2.1$ \\
\hline
\end{tabular}


Table 2. Median low-temperature exotherm $\left(\mathrm{LTE}_{50}\right)$ (mean $\pm \mathrm{SD}$ ) for living (L) and dead (D) flower buds of three sweet cherry selections and 'Bing' cherries during Feb. 1992.

\begin{tabular}{|c|c|c|c|c|c|c|c|c|}
\hline \multirow{3}{*}{$\begin{array}{l}\text { Date } \\
\text { (Feb.) }\end{array}$} & \multicolumn{8}{|c|}{$\mathrm{LTE}_{50}\left({ }^{\circ} \mathrm{C}\right)$} \\
\hline & \multicolumn{2}{|c|}{$7144-3$} & \multicolumn{2}{|c|}{$7147-13$} & \multicolumn{2}{|c|}{$7309-4$} & \multicolumn{2}{|c|}{ Bing } \\
\hline & $\mathrm{L}$ & $\mathrm{D}$ & $\mathrm{L}$ & $\mathrm{D}$ & $\mathrm{L}$ & $\mathrm{D}$ & $\mathrm{L}$ & $\mathrm{D}$ \\
\hline$\overline{11}$ & $-19.8 \pm 2.3$ & $-18.5 \pm 0.8$ & $-18.3 \pm 0.3$ & $-17.7 \pm 1.2$ & $-16.3 \pm 0.3$ & $-12.7 \pm 0.3$ & $-16.9 \pm 0.1$ & $-13.8 \pm 0.4$ \\
\hline 20 & $-18.5 \pm 0.8$ & $-17.8 \pm 0.6$ & $-16.8 \pm 0.0$ & $-16.5 \pm 1.2$ & $-15.8 \pm 0.0$ & $--\mathrm{Z}$ & $-16.3 \pm 0.0$ & $-10.9 \pm 2.4$ \\
\hline 24 & $-16.6 \pm 0.4$ & $-14.7 \pm 1.4$ & $-16.2 \pm 0.1$ & $-12.5 \pm 0.4$ & $-12.7 \pm 0.0$ & & $-15.0 \pm 0.4$ & $-13.0 \pm 2.4$ \\
\hline 26 & $-14.5 \pm 0.4$ & --- & $-14.1 \pm 0.1$ & --- & $-13.3 \pm 1.7$ & --- & $-12.6 \pm 0.0$ & --- \\
\hline
\end{tabular}

${ }^{2}$ No LTEs.

primordia did not produce LTEs. Living flower buds of 7309-4 developed earlier than those of the other selections; thus, LTEs in dead buds disappeared earlier. Buds with living flower primordia produced more LTEs than dead buds, and the differences increased as the buds developed (data not shown).

We conclude that, when a dormant flower primordium is killed by freezing, the tissue water remains intact and compartmentalized so that ice crystals cannot grow. The DTA response remained normal for $>2$ weeks after dormant primordia were killed, a result indicating that water remained in the primordia without evaporating as the buds developed toward the stage at which they normally lose compartmentalization and the ability to supercool deeply, We suggest that factors, probably morphological, that permit compartmentalization are disrupted by freezing. When com- partmentalization is lost, water in the primordium freezes as part of the first LTE.

When many primordia have been killed by freezing, subsequent DTAs are suspect. LTE $_{50}$ estimates will include LTEs from living and dead primordia, which will not respond "in the same manner to factors that influence bud hardiness. Under these circumstances, observing bud injury is advisable.

\section{Literature Cited}

Andrews, P.K., E.L. Proebsting, and G.S. Campbell. 1983, An exotherm sensor for measuring the cold hardiness of deep supercooled flower buds by differential thermal analysis. HortScience 18:77-78.

Biermann, J., C. Stushnoff, and M.J. Burke. 1979. Differential thermal analysis and freezing injury in cold hardy blueberry flower buds. J. Amer. Soc. Hort. Sci. 104:444-449.
Burke, M.J. and C. Stushnoff. 1979. Frost hardiness: A discussion of possible molecular causes of injury with particular reference to deep supercooling of water, p. 197-225. In: H. Mussell and R.C. Staples (eds.). Stress physiology in crop plants. Wiley, New York.

George, M.F., M.L. Burke, and C.J. Weiser. 1974 Supercooling in overwintering azalea flower buds. Plant Physiol. 54:29-35.

Graham, P.R. and R. Mullin. 1976. The determination of lethal freezing temperatures in buds and stems of deciduous azalea by freezing curve method. J. Amer. Soc. Hort. Sci. 101:3-7.

Kader, S.A. and E.L. Proebsting. 1992. Freezing behavior of Prunus, subgenus Padus, flower buds. J. Amer. Soc. Hort. Sci. 117:955-960.

Quamme, H.A. 1974. An exothermic process involved in the freezing injury to flower buds of several prunus species. J. Amer. Soc. Hort. Sci. 99:315-318,

Rehder, A. 1951. Manual of cultivated trees and shrubs. MacMillan, New York. 